Agro-Science Journal of Tropical Agriculture, Food, Environment and Extension Volume 12 Number 1 January 2013 pp 37 - 47

TSSN 1119-7455

\title{
PERFORMANCE OF thevetia peruviana (PERS.) SCHUM. UNDER TWO AGRONOMIC MANAGEMENT PRACTICES (IRRIGATION AND APPLICATION OF IN-ORGANIC FERTILIZERS) IN EDIDI SOUTHERN NIGERIA.
}

\author{
Aboyeji, C. M and Abayomi, Y. A \\ Department of Agronomy, University of Ilorin, Ilorin, Nigeria. \\ Corresponding author- chrismuyiwa@yahoo.com
}

\begin{abstract}
Most studies on T. peruviana have revolved around its clinical, toxicological and pharmacological aspects, while study on its agronomy is scanty. Field experiments were conducted during the 2011 and 2012 growing seasons, at the Research Farms of the Bio-fuel Alternative and Renewable Energy Ltd, Edidi, Kwara State, Nigeria. The study evaluated the effects of supplementary irrigation during the dry season and different rates of nitrogen and phosphorus fertilizers on the growth and yield of the oil crop. The experiment was a $2 \times 3 \times 3$ factorial arranged in split-split plot design. Two levels of irrigation (irrigated and non irrigated) constituted the main plots, three levels of

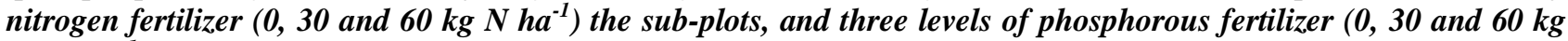
$\left.\mathrm{P}_{2} \mathrm{O}_{5} \mathrm{ha}^{-1}\right)$, the sub-sub-plots. The results showed that irrigating $\mathrm{T}$. peruviana plants significantly improved the vegetative growth parameters, kernel size, number and weight of harvested kernels, but delayed number of days to the first and 50\% flower appearance. Nitrogen fertilizer rate of $60 \mathrm{~kg} \mathrm{~N} \mathrm{ha}$ produced highest values of growth and yield parameters which were significantly better than those of the control, but similar to those of $30 \mathrm{~kg} \mathrm{~N} \mathrm{ha}{ }^{-1}$; and application of $60 \mathrm{~kg} \mathrm{P}_{2} \mathrm{O}_{5} \mathrm{ha}^{-1}$ resulted in early flower appearance and increased the yield parameters, even though the values were statistically similar to those with the application of $30 \mathrm{~kg} \mathrm{P}_{2} \mathrm{O}_{5} \mathrm{ha}^{-1}$. Thus, it can be recommended that T. Peruviana should be irrigated and given fertilizer at a factorial combination of $30 \mathrm{~kg} \mathrm{~N} \mathrm{ha}$ and $30 \mathrm{~kg} \mathrm{P}_{2} \mathrm{O}_{5} \mathrm{ha}^{-1}$ for optimum yield.
\end{abstract}

Keywords: - T. peruviana, Irrigation, Fertilizers, Growth and Yield.

\section{INTRODUCTION}

Thevetia peruviana as potentials source of feed for the animal industry and biofuel to supplement or replace the crude oil are yet to be hanessed. In spite of the high oil content $(67 \%)$ of its kernel (Azam et al., $2005)$ and favourable protein content $(37 \%)$ in the oil composition (Ibiyemi et al., 2002). It has remained only an ornamental, fencing or wasteland plant. It is found in all climatic and vegetation belts of Nigeria and grows to an average height of about 4.5 to $6 \mathrm{~m}$ with deep green linear sword-shaped leaves and funnel shaped flowers.

The plant has seed yield of 52.5 tonnes ha ${ }^{-1}$ per year at full maturity (after 4 years old ) and about 1,750 litres of oil can be obtained from one hectare of waste land (Balusamy and Manrappan, 2007). Its kernel oil has a very good thermal stability (Ibiyemi et al., 1995) and thus has potential for various industrial uses.

Researches have shown that compared to the oil content of other tree born oilseeds (TBO) like karanja, Jatropha and neem (Gübitz et al., 1999, Srivastava and Verma, 2008) the oil content of $T$. peruviana kernel is very high, hence, it is a potential oil seed crop for bio-diesel production.
Adequate water and nutrient supply are important factors affecting optimal plant growth and successful crop production (Ashraf et al., 2007). Assaf et al. (1982) observed that one of the major problems in irrigating crops is finding practical measures for determining the frequency and amount of water application. Such measures may also help evaluate crop response to a seasonal irrigation regime and thus improve the irrigation program for subsequent seasons.

For a newly introduced crop, it is important to assess the appropriate production technology under different environments. Among many plant growth factors, the nutritional requirements of the crop are considered to be the most important factor (Singh et al., 1989). Insufficient fertilizer can slow plant growth or cause deficiency symptoms.

Yin et al. (2010) observed that different levels of nitrogen(N) fertilizer significantly affected growth, development, kernel set and yield of physic nut. Several investigators reported that an increase in $\mathrm{N}$ rate is associated with an increase in yield of different species of fruit trees (Shawky et al,. 1973; Koo et al. 1974). Excessive $\mathrm{N}$ fertilization has been reported to result in excessive vegetative growth of fruit bearing trees, which 
will reduce flower bud formation and consequently reduce fruit yield (Menzel et al., 1994).

Phosphorous is an essential nutrient for root formation, flowering, fruiting and ripening (Gayle et al., 2001). It hastens maturity of crops grown on soils low in phosphorus. It has been observed that $T$. peruviana plant response to phosphorus follows the normal pattern for most plants (Manchanda et al., 1982; Prasad and Shina, 1981). Phosphorus deficiencies late in the growing season affect both seed development and normal crop maturity (Scheffel 1999).

The objective of the present study was therefore, to evaluate the response of $T$. peruviana to fertilizer application and irrigation with a view to determining the requirements for large scale production of the crop.

\section{MATERIALS AND METHODS}

The study was carried out in 2011 and 2012 at the Research Farms of the Bio-fuel Alternate and Renewable Energy Ltd, Edidi, Kwara State, Latitude $8^{\circ}$ $14^{\prime} \mathrm{N}$, Longitude $4^{\circ} 56^{\prime} \mathrm{E}$ and an elevation of $447 \mathrm{~m}$ above sea level in the southern Guinea savanna of Nigeria.

Pre-cropping soil samples were randomly taken from six spots using the soil auger at $0-30 \mathrm{~cm}$ soil depth from the experimental field. The samples collected were bulked to obtain a composite sample for routine soil analysis in the laboratory to determine some physicochemical properties of the soil. The experimental design was a 2 × $3 \times 3$ factorial in Randomized Complete Block with split-split-plot arrangement model and each treatment was replicated three times.

Two irrigation regimes [irrigated (IR) and nonirrigated (NIR)], three rates of phosphorus fertilizer [0 $\left(\mathrm{P}_{0}\right), 30\left(\mathrm{P}_{30}\right)$ and $60\left(\mathrm{P}_{60}\right) \mathrm{kg} \mathrm{P}_{2} \mathrm{O}_{5}$ ha $\left.^{-1}\right]$ and three rates of nitrogen fertilizer $\left[0\left(\mathrm{~N}_{0}\right), 30\left(\mathrm{~N}_{30}\right)\right.$ and $60\left(\mathrm{~N}_{60}\right) \mathrm{kg} \mathrm{N}^{-}$ ${ }^{1}$ ] were evaluated. Irrigation was in the main plots, while nitrogen and phosphorus fertilizers were in the sub-plots and sub-sub plots, respectively.

The size of each sub-sub plot in the experiment was $10.0 \mathrm{~m} \times 4.0 \mathrm{~m}=\left(40 \mathrm{~m}^{2}\right)$ and there were eighteen (18) plots in each replicate.

The seeds used were collected from the wild in the year of each experiment. The dried pericarp of the mature seeds were removed The seeds were cleaned and sun-dried for three days before sowing.

Land preparation was done using the tractor. The land was ploughed once and harrowed twice to give a well pulverized soil. Thereafter, the field layout was carried out to mark out the appropriate number of treatment plots.

The seeds were pre-germinated in a covered and protected nursery in plastic bags for 6 weeks before they were transplanted to the field at a spacing of $2 \mathrm{~m}$ by $2 \mathrm{~m}$ on the flat. The total plant population was 2,500 plants $\mathrm{ha}^{-1}$.

Nitrogen fertilizer in form of Urea $(46 \% \mathrm{~N})$ was applied at the rate of $0 \mathrm{~kg} \mathrm{~N} \mathrm{ha}^{-1}, 30 \mathrm{~kg} \mathrm{~N} \mathrm{ha}^{-1}$ and $60 \mathrm{~kg}$
$\mathrm{N} \mathrm{ha}^{-1}$ while phosphorus fertilizer in the form of single superphosphate $\left(18 \% \mathrm{P}_{2} \mathrm{O}_{5}\right)$ was applied at the rate of 0 $\mathrm{kg} \mathrm{P}_{2} \mathrm{O}_{5} \mathrm{ha}^{-1}, 30 \mathrm{~kg} \mathrm{P}_{2} \mathrm{O}_{5} \mathrm{ha}^{-1}$ and $60 \mathrm{~kg} \mathrm{P}_{2} \mathrm{O}_{5} \mathrm{ha}^{-1}$.

Phosphorus fertilizer was applied once at transplanting while nitrogen fertilizer was applied in two split doses. The first dose of nitrogen $\left(0 \mathrm{~kg} \mathrm{~N} \mathrm{ha}{ }^{-1}, 15 \mathrm{~kg}\right.$ $\mathrm{N} \mathrm{ha}^{-1}$ and $30 \mathrm{~kg} \mathrm{~N} \mathrm{ha}^{-1}$ ) was applied at 2 weeks after transplanting while the second dose of nitrogen $(0 \mathrm{~kg} \mathrm{~N}$ $\mathrm{ha}^{-1}, 15 \mathrm{~kg} \mathrm{~N} \mathrm{ha}^{-1}$ and $30 \mathrm{~kg} \mathrm{~N} \mathrm{ha}^{-1}$ ) was applied at 6 weeks after transplanting by side placement at about 8-10 $\mathrm{cm}$ away from the base of the plant.

The most prominent pest of Thevetia peruviana is the grasshoppers (Zonozerus veriegatus) which appeared mostly during the dry season. They defoliate the leaves and reduce the photosynthetic activities of the plants sometimes leading to death of the plant if not controlled. When the grasshoppers appeared at the onset of flowering, 30g Cypermetrin/ 250g dimethoathe a systemic insecticide was used at the rate of $1.5 \mathrm{~kg}$ a.i ha ${ }^{-1}$ to control the infestation and prevent them from defoliating the leaves. In the same vein and at the same rate, when both flowers and fruits abortion were noticed 30g Cypermetrin/ 250g dimethoathe was used to control insects and ants sucking juice of the flowers. Insecticide application was done at 14 days interval.

Each replicate in the experiment was divided into two equal parts (irrigated and non irrigated). One part was irrigated continuously for one hour twice every week with the aid of overhead sprinklers during the dry season, while the other part was left un-irrigated. In other to prevent seepage of water from irrigated treatments to non irrigated treatments, barrier ridges were made across each irrigated treatments. Irrigation was introduced immediately after the the rainy season.

Glyphosate (systemic and non-selective herbicide) was used at the rate of $2.5 \mathrm{~kg}$ a.i ha ${ }^{-1}$ at intervals of 6,18 and 26 weeks after transplanting using Knapsack sprayer to control both annual and perennial weeds. The herbicide was carefully applied so that it does not contact with any green part of the tree, including the trunk.

Mature fruits were manually collected after reaching maturity stage (between $2 \frac{1}{2}$ and 3 months after flowering and between 10 and 12 months after planting) as indicated by the black colour of the succulent outer covering. The succulent outer covering of the seeds were removed and the seeds dried, counted and weighed separately per plot.

The vegetative growth parameters (plant height, number of primary branches at 20,24, 28 and 32 weeks after transplanting), number of days to first and 50\% flower appearance, number of days from planting and flowering to fruit maturity, dry weight of 10 kernels, kernel length and girth as well as kernel yield per plot were measured.

The data collected were subjected to analysis of variance (ANOVA) based on the split-split- plot model (Gomez and Gomez, 1984) using Statistical Analysis Software (SAS, 2000). The significant treatment means 
were compared using the Least Significant Difference (LSD) at 0.05 level of probability $(\mathrm{p} \leq 0.05)$.

\section{RESULTS}

The heights of Thevetia peruviana plant as influenced by the irrigation regimes, rates of nitrogen and phosphorus fertilizers in 2011 and 2012 are presented on Tables 1 and 2, respectively. It was observed that in 2011 after irrigating the plants, there was a significant increase in plant height as compared to non-irrigated plants, while in 2012, the differences in plant height between the two irrigation regimes were not significant.

In 2011 and 2012, increase in rates of nitrogen fertilizer from 0 to $30 \mathrm{~kg} \mathrm{~N}^{-1}$ significantly increased the plant height while further increase in nitrogen fertilizer to $60 \mathrm{~kg} \mathrm{~N} \mathrm{ha}^{-1}$ increased the plant height but the value was statistically similar with that obtained with the application of $30 \mathrm{~kg} \mathrm{~N} \mathrm{ha}^{-1}$.

Varying rates of phosphorus fertilizer had no significant effect on the plant height in 2011 and at 28 and 32 WAT in 2012 while the effect of varying rates of phosphorus fertilizer from 0 to $30 \mathrm{~kg} \mathrm{P}_{2} \mathrm{O}_{5} \mathrm{ha}^{-1}$ was significant on the plant height at 20 and 24 WAT in 2012.

The interaction between nitrogen and phosphorus and those among irrigation regimes, nitrogen and phosphorus were not significant on the plant height.

The effects of irrigation regimes, rates of application of nitrogen and phosphorus fertilizers on the number of primary branches in 2011 and 2012 are shown on Tables 3 and 4, respectively. At 20 and 24 WAT (before irrigation) in 2011 and at all weeks after transplanting in 2012, the difference in the number of primary branches between the two irrigation regimes were not significant but increase in the number of primary branches was significant at 28 and 32 WAT in 2011.

Application of $30 \mathrm{~kg} \mathrm{~N} \mathrm{ha}{ }^{-1}$ significantly increased the number of primary branches at all weeks after transplanting in 2011 and 2012. Further increase in nitrogen fertilizer up to $60 \mathrm{~kg} \mathrm{~N} \mathrm{ha}^{-1}$ reduced the number of primary branches but the value was statistically similar to that with the application of $30 \mathrm{~kg} \mathrm{~N} \mathrm{ha}^{-1}$.

Table 1: Effects of irrigation and rates of nitrogen and phosphorus fertilizers on the plant height $(\mathrm{cm})$ of Thevetia peruviana in the year 2011

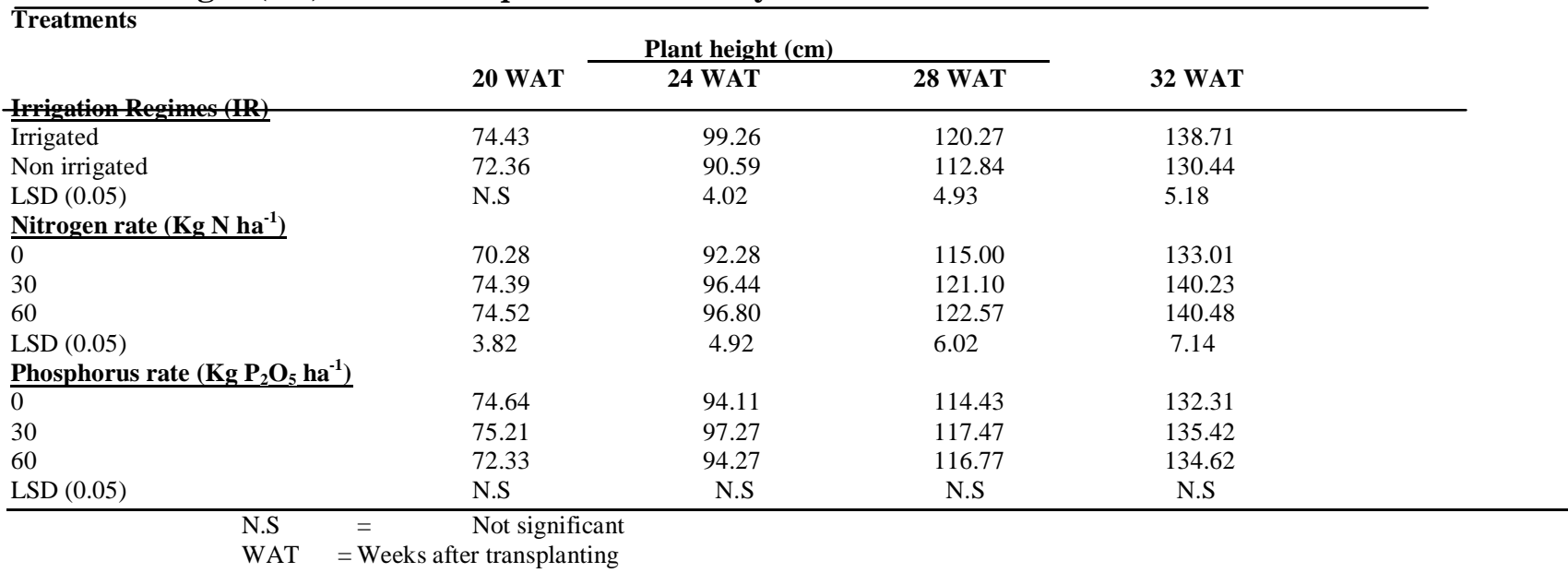


Table 2: Effects of irrigation and rates of nitrogen and phosphorus fertilizers on the plant height (cm) of Thevetia peruviana in the year 2012

\begin{tabular}{|c|c|c|c|c|}
\hline \multicolumn{5}{|l|}{ Treatments } \\
\hline & \multirow[b]{2}{*}{20 WAT } & \multicolumn{2}{|c|}{ Plant height $(\mathrm{cm})$} & \multirow[b]{2}{*}{32 WAT } \\
\hline & & 24 WAT & 28 WAT & \\
\hline \multicolumn{5}{|c|}{ Trrigation Regimes (IR) } \\
\hline Irrigated & 93.47 & 111.19 & 138.67 & 144.87 \\
\hline Non irrigated & 93.67 & 112.56 & 136.32 & 144.82 \\
\hline $\operatorname{LSD}(0.05)$ & N.S & N.S & N.S & N.S \\
\hline \multicolumn{5}{|c|}{ Nitrogen rate $\left(\mathrm{Kg} \mathrm{N} \mathrm{ha}^{-1}\right)$} \\
\hline 0 & 89.30 & 108.56 & 130.42 & 140.73 \\
\hline 30 & 91.87 & 113.01 & 138.48 & 149.97 \\
\hline 60 & 92.83 & 114.03 & 139.58 & 150.83 \\
\hline $\operatorname{LSD}(0.05)$ & 0.87 & 3.59 & 6.14 & 7.08 \\
\hline \multicolumn{5}{|c|}{ Phosphorus rate $\left(\mathrm{Kg}_{2} \mathrm{P}_{5} \mathrm{ha}^{-1}\right)$} \\
\hline 0 & 90.23 & 109.59 & 136.08 & 141.90 \\
\hline 30 & 93.43 & 114.01 & 139.97 & 147.07 \\
\hline 60 & 92.33 & 112.06 & 136.43 & 145.57 \\
\hline $\operatorname{LSD}(0.05)$ & 2.01 & 3.40 & N.S & N.S \\
\hline & $\begin{array}{l}\text { Not signi } \\
\text { er transpla }\end{array}$ & & & \\
\hline
\end{tabular}

Table 3: Effects of irrigation and rates of nitrogen and phosphorus fertilizers on the number of primary branches (number per tree) of Thevetia peruviana in the year 2011

\begin{tabular}{|c|c|c|c|c|}
\hline \multirow[t]{2}{*}{ Treatments } & \multirow[b]{2}{*}{$20 \mathrm{WAT}$} & \multicolumn{2}{|c|}{ Number of primary branches } & \multirow[b]{2}{*}{32 WAT } \\
\hline & & 24 WAT & 28 WAT & \\
\hline \multicolumn{5}{|c|}{ Irrigation Regimes (IR) } \\
\hline Irrigated & 16.30 & 25.14 & 32.80 & 37.11 \\
\hline Non irrigated & 16.39 & 25.04 & 28.90 & 34.56 \\
\hline $\operatorname{LSD}(0.05)$ & N.S & N.S & 1.74 & 2.00 \\
\hline \multicolumn{5}{|c|}{ Nitrogen rate $\left(\mathrm{Kg} \mathrm{N} \mathrm{ha}^{-1}\right)$} \\
\hline 0 & 15.73 & 22.48 & 28.33 & 33.09 \\
\hline 30 & 17.93 & 25.70 & 31.32 & 36.73 \\
\hline 60 & 17.87 & 25.10 & 31.90 & 34.38 \\
\hline $\operatorname{LSD}(0.05)$ & 1.34 & 1.83 & 2.02 & 2.41 \\
\hline \multicolumn{5}{|c|}{ Phosphorus rate $\left(\mathrm{Kg} \mathrm{P}_{2} \mathrm{O}_{5} \mathrm{ha}^{-1}\right)$} \\
\hline 0 & 14.70 & 23.81 & 29.80 & 34.89 \\
\hline 30 & 18.10 & 26.67 & 32.67 & 38.72 \\
\hline 60 & 17.73 & 24.80 & 31.80 & 36.59 \\
\hline $\operatorname{LSD}(0.05)$ & 1.34 & 1.83 & 2.02 & 2.41 \\
\hline
\end{tabular}

N.S $=\quad$ Not significant

WAT $=$ Weeks after transplanting 
Table 4: Effects of irrigation and rates of nitrogen and phosphorus fertilizers on the number

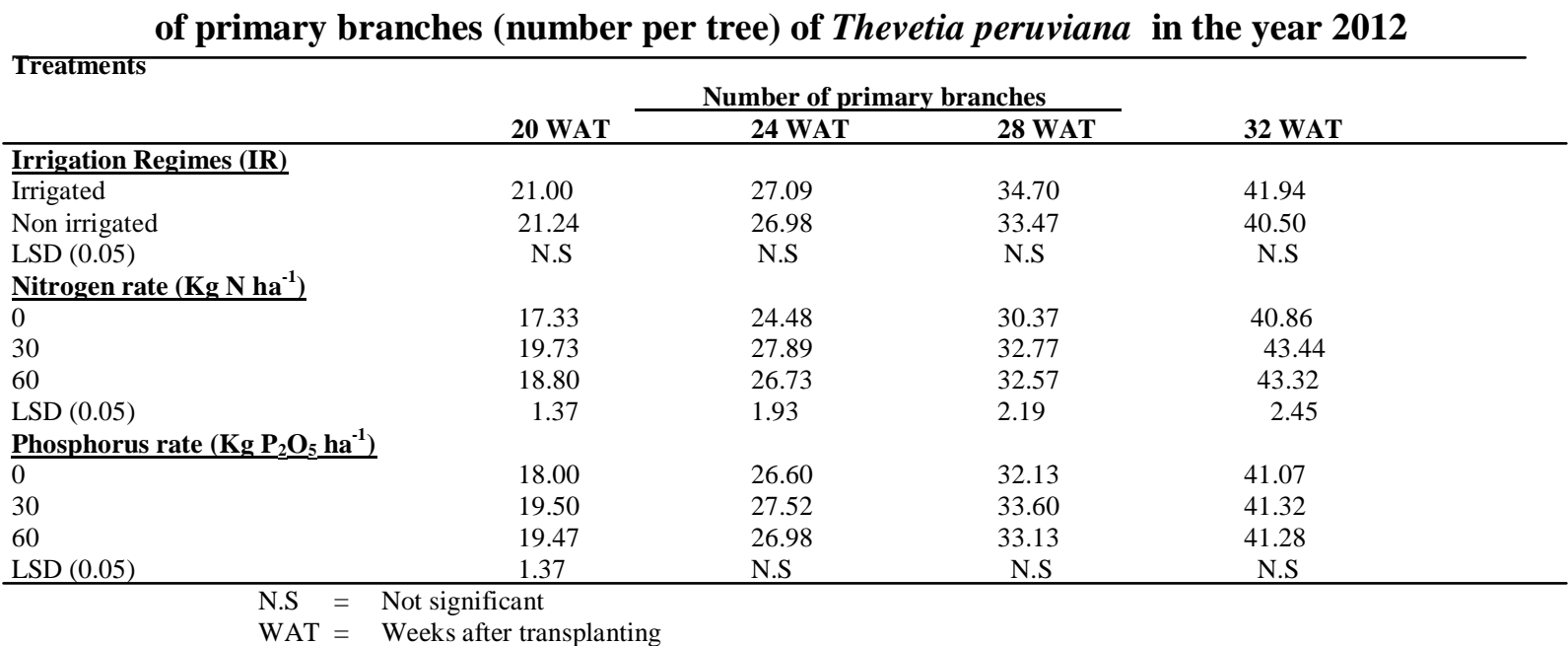

At all weeks after transplanting in 2011 and at $20 \mathrm{WAT}$ in 2012, application of $30 \mathrm{~kg} \mathrm{P}_{2} \mathrm{O}_{5}$ ha $^{-1}$ significantly increased the number of primary branches over the no phosphorus treatment and the application of $30 \mathrm{~kg} \mathrm{P}_{2} \mathrm{O}_{5}$ $\mathrm{ha}^{-1}$ showed value statistically similar to that with the application of $60 \mathrm{~kg} \mathrm{P}_{2} \mathrm{O}_{5} \mathrm{ha}^{-1}$. However, at 24, 28 and 32 WAT in 2012, the number of primary branches did not vary significantly with the application of varying rates of phosphorus fertilizer. The plots without phosphorus had the least number of primary branches in both years of the study. There was no significant interaction effects of irrigation regimes, nitrogen and phosphorus fertilizers on number of primary branches.

Table 5 showed the effects of irrigation regimes, rates of nitrogen and phosphorus fertilizers on the number of days to the first flower appearance in 2011 and 2012. The difference in the number of days to the first flower appearance between the irrigated and non- irrigated plants was not significant in 2011. Non irrigated plants flowered earlier than the irrigated plants in 2012.
In both years and in the two years average, the application of $60 \mathrm{~kg} \mathrm{~N} \mathrm{ha}^{-1}$ significantly increased the number of days to the first flower appearance, while the plants without nitrogen and those treated with $30 \mathrm{~kg} \mathrm{~N}$ $\mathrm{ha}^{-1}$ flowered much earlier than plants treated with 60 $\mathrm{kg} \mathrm{N} \mathrm{ha}{ }^{-1}$. There was no significant difference in the number of days to first flower appearance between the control and the application of $30 \mathrm{~kg} \mathrm{~N} \mathrm{ha}^{-1}$.

The number of days to the first flower appearance decreased with increasing rates of phosphorus fertilizer in 2011, 2012 and in the two years average. There was a significant reduction in the number of days to first flower appearance with increasing rates of phosphorus fertilizer in 2012. The effect of varying the rates of phosphorus fertilizer was not significant in 2011.

The interactions between irrigation, nitrogen and phosphorus fertilizers on number of primary branches were not significant in both years. 
Table 5: Effects of irrigation and rates of nitrogen and phosphorus fertilizers on the number of days to first flower appearance of Thevetia peruviana in 2011, 2012 and in the 2 years average

\begin{tabular}{|c|c|c|c|}
\hline \multirow[t]{2}{*}{ Treatments } & \multicolumn{3}{|c|}{ Days to first flower appearance } \\
\hline & Year 2011 & Year 2012 & Average of 2 years mean \\
\hline \multicolumn{4}{|c|}{ Irrigation Regimes (IR) } \\
\hline Irrigated & 242 & 286 & 264 \\
\hline Non irrigated & 239 & 283 & 261 \\
\hline $\operatorname{LSD}(0.05)$ & N.S & 2.49 & 2.55 \\
\hline \multicolumn{4}{|c|}{ Nitrogen rate $\left(\mathrm{Kg} \mathrm{N} \mathrm{ha}^{-1}\right)$} \\
\hline 0 & 238 & 281 & 259 \\
\hline 30 & 237 & 283 & 260 \\
\hline 60 & 246 & 287 & 266 \\
\hline $\operatorname{LSD}(0.05)$ & 5.05 & 3.96 & 3.13 \\
\hline \multicolumn{4}{|c|}{ Phosphorus rate $\left(\mathrm{Kg} \mathrm{P}_{2} \mathrm{O}_{5}\right.$ ha $\left.^{-1}\right)$} \\
\hline 0 & 242 & 287 & 264 \\
\hline 30 & 239 & 284 & 262 \\
\hline 60 & 239 & 283 & 261 \\
\hline $\operatorname{LSD}(0.05)$ & N.S & 3.96 & 3.13 \\
\hline
\end{tabular}

The effects of irrigation regimes and rates of nitrogen and phosphorus fertilizers application on the number of days to 50\% flower appearance in 2011, 2012 and in the two years average are presented on Table 6. Irrigating the plants significantly increased the number of days to 50\% flower appearance in 2011, 2012 and in the two years average while the number of days to $50 \%$ flowering reduced when the plants were not irrigated.

There was a significant increase in the number of days to $50 \%$ flower appearance when the application of nitrogen fertilizer was increased from 0 to $60 \mathrm{~kg} \mathrm{~N}$ $\mathrm{ha}^{-1}$ in both years and in the two years average, while the values were statistically similar with the application of $30 \mathrm{~kg} \mathrm{~N} \mathrm{ha}^{-1}$. The earliest number of days to $50 \%$ flower appearance was observed under the control, non application of nitrogen fertilizer.

In 2011 and in the two years average, the zero phosphorus fertilizer application significantly reduced the number of days to $50 \%$ flower appearance, while the difference in the number of days to $50 \%$ flower appearance was not significantly different with the application of 30 and $60 \mathrm{~kg} \mathrm{P}_{2} \mathrm{O}_{5} \mathrm{ha}^{-1}$. In 2012, varying the rates of phosphorus fertilizer application did not show significant differences in the number of days to $50 \%$ flower appearance.
There was no significant interaction effects between irrigation regimes, nitrogen and phosphorus fertilizers on the number of days to $50 \%$ flowering.

The response of the shrub in terms of number of days from planting to fruit maturity under irrigation regimes, rates of nitrogen and phosphorus fertilizers in 2011, 2012 and in the two years average is presented on Table 7. The effect of irrigation regimes was not significant on the number of days to fruit maturity from planting in both years and in the two years average.

In 2011, 2012 and in the two years average, plants without nitrogen fertilizer application matured earlier than those with 30 and $60 \mathrm{~kg} \mathrm{~N} \mathrm{ha}^{-1}$ but the difference was not significant in 2012. The difference between the application of 30 and $60 \mathrm{~kg} \mathrm{~N} \mathrm{ha}^{-1}$ on the number of days from planting to fruit maturity was statistically similar in 2011 and in the two years average.

Application of varying rates of phosphorus fertilizer from 0 to $60 \mathrm{~kg} \mathrm{P}_{2} \mathrm{O}_{5} \mathrm{ha}^{-1}$ resulted in a non significant reduction in the number of days from planting to fruit maturity in 2011 and in the two years average. In 2012, application of $60 \mathrm{~kg} \mathrm{P}_{2} \mathrm{O}_{5} \mathrm{ha}^{-1}$ significantly reduced the number of days from planting to fruit maturity when compared with the control although the value was statistically similar with that of the application of $30 \mathrm{~kg} \mathrm{P}_{2} \mathrm{O}_{5} \mathrm{ha}^{-1}$. 
Table 6: Effects of irrigation and rates of nitrogen and phosphorus fertilizers on the number of days to $50 \%$ flower appearance of Thevetia peruviana in 2011, 2012 and in the 2 years average

\begin{tabular}{|c|c|c|c|}
\hline Treatments & Days to & ver appeara & \\
\hline & Year 2011 & Year 2012 & Average of 2 vears \\
\hline Irrigation Reg & & & \\
\hline Irrigated & 281 & 295 & 288 \\
\hline Non irrigated & 266 & 289 & 278 \\
\hline $\operatorname{LSD}(0.05)$ & 11.05 & 2.10 & 5.48 \\
\hline Nitrogen rate & & & \\
\hline 0 & 271 & 291 & 281 \\
\hline 30 & 280 & 293 & 287 \\
\hline 60 & 285 & 295 & 290 \\
\hline $\operatorname{LSD}(0.05)$ & 13.54 & 2.58 & 6.71 \\
\hline Phosphorus ra & & & \\
\hline 0 & 289 & 294 & 291 \\
\hline 30 & 268 & 292 & 280 \\
\hline 60 & 265 & 291 & 278 \\
\hline $\operatorname{LSD}(0.05)$ & 13.54 & N.S & 6.71 \\
\hline
\end{tabular}

Table 7: Effects of irrigation and rates of nitrogen and phosphorus fertilizers on the number of days from planting to fruit maturity of Thevetia peruviana in 2011, 2012 and in the 2 years average

\begin{tabular}{|c|c|c|c|}
\hline \multirow[t]{2}{*}{ Treatment } & \multicolumn{3}{|c|}{ Days from planting to fruit maturity } \\
\hline & Year 2011 & Year 2012 & Average of 2 years \\
\hline \multicolumn{4}{|c|}{ Irrigation Regimes (IR) } \\
\hline Irrigated & 321 & 373 & 347 \\
\hline Non irrigated & 316 & 371 & 344 \\
\hline $\operatorname{LSD}(0.05)$ & N.S & N.S & N.S \\
\hline \multicolumn{4}{|c|}{ Nitrogen rate $\left(\mathrm{Kg} \mathrm{N} \mathrm{ha}^{-1}\right)$} \\
\hline 0 & 314 & 370 & 342 \\
\hline 30 & 321 & 372 & 347 \\
\hline 60 & 322 & 372 & 347 \\
\hline $\operatorname{LSD}(0.05)$ & 6.25 & N.S & 4.74 \\
\hline \multicolumn{4}{|c|}{ Phosphorus rate $\left(\mathrm{Kg}_{2} \mathrm{P}_{5} \mathrm{ha}^{-1}\right)$} \\
\hline 0 & 322 & 373 & 348 \\
\hline 30 & 314 & 372 & 343 \\
\hline 60 & 320 & 370 & 345 \\
\hline $\operatorname{LSD}(0.05)$ & N.S & 3.06 & N.S \\
\hline
\end{tabular}

kernels in 2011, while the application of $60 \mathrm{~kg} \mathrm{~N} \mathrm{ha}^{-1}$ resulted in a significantly higher kernels weight in

There were no significant interaction effects between nitrogen, phosphorus and irrigation regimes on number of days to fruit maturity.

The responses of the plant in terms of weight of the harvested kernels to irrigation regimes, rates of nitrogen and phosphorus fertilizers in 2011 and 2012, and the two years average are presented on Table 8 . The results showed that, irrigating the plants resulted in an increase in the weight of harvested kernels in 2011, 2012 and in the two years average. However, the increase in the weight of kernels harvested was only significant in 2011.

There was no significant effect of the varying rates of nitrogen fertilizer on weight of harvested 2012.

Application of phosphorus fertilizer from 0 to $30 \mathrm{~kg} \mathrm{P}_{2} \mathrm{O}_{5} \mathrm{ha}^{-1}$ significantly increased the weight of harvested kernels in 2010 and in the two years average, while further increase in phosphorus fertilizer to $60 \mathrm{~kg}$ $\mathrm{P}_{2} \mathrm{O}_{5}$ ha $^{-1}$ resulted in a non significant increase in the weight of harvested kernels. In 2012, application of phosphorus fertilizer had no significant effect on the weight of harvested kernels.

There was no significant interactions between irrigation regimes, nitrogen and phosphorus fertilizers on the weight of harvested kernels. 
Table 8: Effects of irrigation and rates of nitrogen and phosphorus fertilizers on the weight of harvested kernels $\left(\mathrm{kg} \mathrm{ha}^{-1}\right)$ of Thevetia peruviana in 2011, 2012 and in the 2 years average

\begin{tabular}{|c|c|c|c|}
\hline Treatments & Weight of 1 & $\left(\mathrm{~kg} \mathrm{ha}^{-1}\right)$ & \\
\hline & Year 2011 & Year 2012 & Average of 2 years \\
\hline Imrigation Regimes ( $(\mathbf{R})$ & & & \\
\hline Irrigated & 24.42 & 29.57 & 26.99 \\
\hline Non irrigated & 12.35 & 28.05 & 20.20 \\
\hline $\operatorname{LSD}(0.05)$ & 6.95 & N.S & N.S \\
\hline Nitrogen rate $\left(\mathrm{Kg} \mathrm{N} \mathrm{ha}^{-1}\right)$ & & & \\
\hline 0 & 15.20 & 20.56 & 17.88 \\
\hline 30 & 18.88 & 20.62 & 19.75 \\
\hline 60 & 21.07 & 45.26 & 33.17 \\
\hline $\operatorname{LSD}(0.05)$ & N.S & 17.27 & 9.38 \\
\hline$\underline{\text { Phosphorus rate }\left(\mathrm{Kg} \mathbf{P}_{2}\right.} \underline{\mathrm{O}}$ & & & \\
\hline 0 & 10.04 & 21.78 & 15.91 \\
\hline 30 & 21.22 & 29.82 & 25.52 \\
\hline 60 & 23.88 & 26.83 & 25.37 \\
\hline $\operatorname{LSD}(0.05)$ & 8.50 & N.S & 9.37 \\
\hline
\end{tabular}

The kernel length of $T$. peruviana as influenced by the irrigation regime and the application rates of nitrogen and phosphorus fertilizers in 2011, 2012 and in the two years average is shown on Table 9. Irrigation during the dry season did not significantly affect the kernel length in 2012 and in the two years average. However, in 2011, irrigation significantly increased the kernel length.

There was a significant increase in the kernel length when the rate of nitrogen fertilizer was increased from 0 to $30 \mathrm{~kg} \mathrm{~N} \mathrm{ha}^{-1}$ in 2011, while further increase in nitrogen fertilizer to $60 \mathrm{~kg} \mathrm{~N} \mathrm{ha}^{-1}$ reduced the kernel length, although the value was not significantly different from that of the application of $30 \mathrm{~kg} \mathrm{~N} \mathrm{ha}^{-1}$. In 2012 and in the two years average, the effects of $\mathrm{N}$ fertilizer application were not significant for the parameter.

Application of phosphorus fertilizer from 0 to $30 \mathrm{~kg} \mathrm{P}_{2} \mathrm{O}_{5}$ ha $^{-1}$ increased the kernel length in both years, but the increase was only significant in 2011 and in the two years average. Further increase in the application of $\mathrm{P}$ fertilizer up to $60 \mathrm{~kg} \mathrm{P}_{2} \mathrm{O}_{5} \mathrm{ha}^{-1}$ decreased the kernel length although the value was statistically similar with that at the application of $30 \mathrm{~kg}$ $\mathrm{P}_{2} \mathrm{O}_{5} \mathrm{ha}^{-1}$. Significant interaction effect of irrigation and phosphorus fertilizer on kernel length (Table 10) showed that the application of $30 \mathrm{~kg} \mathrm{P}_{2} \mathrm{O}_{5} \mathrm{ha}^{-1}$ was optimum for the kernel length when plants were irrigated, whereas with no irrigation, the application of $60 \mathrm{~kg} \mathrm{P}_{2} \mathrm{O}_{5} \mathrm{ha}^{-1}$ was the best rate for the trait.

Table 11 shows the effects of irrigation regime, nitrogen and phosphorus fertilizers on kernel girth in 2011 and 2012. Kernel girth was significantly increased in 2011 when the plants were irrigated, while in 2012 and in the two years average, the effect of irrigation was not significant for the kernel girth.

Application of $\mathrm{N}$ fertilizer had no appreciable effects on the kernel girth in both years. However, application of phosphorus fertilizer at the rate of $30 \mathrm{~kg}$ $\mathrm{P}_{2} \mathrm{O}_{5}$ ha $^{-1}$ increased the kernel girth in both years and in the two years average, but the difference was not significant in 2011.

There were no significant interaction effects of the three factors on the kernel girth. 
Table 9: Effects of irrigation and rates of Nitrogen and Phosphorus fertilizers on the kernel length (cm) of Thevetia peruviana in 2011, 2012 and in the 2 years average

\begin{tabular}{|c|c|c|c|}
\hline \multirow[t]{2}{*}{ Treatments } & \multicolumn{2}{|c|}{ Kernel length (cm) } & \multirow[b]{2}{*}{ Average of 2 years } \\
\hline & Year 2011 & Year 2012 & \\
\hline Irrigation Regimes $(\mathbf{I R})$ & & & \\
\hline Irrigated & 3.34 & 2.84 & 3.09 \\
\hline Non irrigated & 3.24 & 2.81 & 3.03 \\
\hline $\operatorname{LSD}(0.05)$ & 0.10 & N.S & N.S \\
\hline \multicolumn{4}{|l|}{ Nitrogen rate $\left(\mathrm{Kg} \mathrm{N} \mathrm{ha}^{-1}\right)$} \\
\hline 0 & 3.21 & 2.80 & 3.00 \\
\hline 30 & 3.37 & 2.80 & 3.09 \\
\hline 60 & 3.29 & 2.90 & 3.10 \\
\hline $\operatorname{LSD}(0.05)$ & 0.12 & N.S & N.S \\
\hline \multicolumn{4}{|c|}{ Phosphorus rate $\left(\mathrm{Kg}_{2} \mathrm{P}_{2} \underline{\mathrm{O}}_{5} \underline{\mathrm{ha}}^{-1}\right)$} \\
\hline 0 & 3.21 & 2.77 & 2.99 \\
\hline 30 & 3.36 & 2.86 & 3.11 \\
\hline 60 & 3.30 & 2.85 & 3.08 \\
\hline $\operatorname{LSD}(0.05)$ & 0.13 & N.S & 0.09 \\
\hline \multicolumn{4}{|l|}{ Interaction } \\
\hline $\mathrm{IR} \times \mathrm{P}$ & $*$ & N.S & N.S \\
\hline$k^{*}$ & at 5\% leve & & \\
\hline
\end{tabular}

Table 10: Interactive effects of Irrigation and Phosphorus fertilizer on the Kernel length (cm) of Thevetia peruviana in 2011

\begin{tabular}{lcc}
\hline Phosphorus rate $\left(\mathbf{K g} \mathbf{P}_{\mathbf{2}} \underline{\mathbf{O}}_{\mathbf{5}} \mathbf{h a}^{-\mathbf{1}}\right)$ Irrigated & Non irrigated & \\
\hline 0 & 3.22 & 3.17 \\
30 & 3.44 & 3.21 \\
60 & 3.37 & 3.34 \\
\hline LSD $(0.05)$ & & 0.03
\end{tabular}

Table 11: Effects of irrigation and rates of Nitrogen and Phosphorus fertilizers on the kernel girth $(\mathrm{cm})$ of Thevetia peruviana in 2011,2012 and in the 2 years average

\begin{tabular}{|c|c|c|c|c|}
\hline \multirow[t]{2}{*}{ Treatments } & \multicolumn{3}{|c|}{ Kernel girth } & \\
\hline & Year 2011 & Year 2012 & Average of 2 years & \\
\hline \multicolumn{5}{|c|}{ Irrigation Regimes (IR) } \\
\hline Irrigated & 1.64 & & 1.48 & 1.56 \\
\hline Non irrigated & $1.59 \mathrm{~b}$ & & 1.48 & 1.54 \\
\hline $\operatorname{LSD}(0.05)$ & 0.04 & & N.S & N.S \\
\hline \multicolumn{5}{|c|}{ Nitrogen rate $\left(\mathrm{Kg} \mathrm{N} \mathrm{ha}^{-1}\right)$} \\
\hline 0 & 1.60 & & 1.45 & 1.53 \\
\hline 30 & 1.62 & & 1.49 & 1.56 \\
\hline 60 & 1.62 & & 1.50 & 1.56 \\
\hline $\operatorname{LSD}(0.05)$ & N.S & & N.S & N.S \\
\hline \multicolumn{5}{|c|}{ Phosphorus rate $\left(\mathrm{Kg}_{2} \mathrm{P}_{2} \mathrm{O}_{5}\right.$ ha $\left.^{-1}\right)$} \\
\hline 0 & 1.59 & & 1.46 & 1.53 \\
\hline 30 & 1.63 & & 1.52 & 1.56 \\
\hline 60 & 1.63 & & 1.46 & 1.55 \\
\hline $\operatorname{LSD}(0.05)$ & N.S & & 0.05 & 0.04 \\
\hline
\end{tabular}

\section{DISCUSSION}

Irrigating $T$. peruviana plants resulted in significant increases in the vegetative traits. The significant increases in plant height and number of branches may be due to more availability of moisture which may have resulted in increased physiological processes like photosynthesis, cell turgidity, growth of cells and tissues and increased nutrients uptake. Dehghanisanij et al. (2007) reported that vegetative growth significantly increased as the rate of irrigation applied in different stone fruit trees (cherries, apricots, plums and nactarines) increased.

The result indicated that irrigation water delayed number of days to first flower appearance, number of days to $50 \%$ flower appearance, and number of days to fruit maturity. Similar results were reported by Tovar et al. (2002) in irrigated olive trees.

The earliness to attain flowering and maturity without irrigation may be as a result of reduction in the water status of the plants leading to reduction in the activities of the meristematic tissues. This result is in line with the findings of Berenguer et al. (2002) who observed that flower initiation and maturity of olive fruit (Olea europaea) were accelerated with dryness. However, the more severe the water stress was, the earlier the plant attains anthesis.

There was an increase in the kernel length and kernel girth when the plants were irrigated. This could be 
as a result of taller plants and higher number of primary branches recorded under irrigation which increased light interception for the process of photosynthesis leading to higher accumulation of photosynthates (assimilates) in the seeds (sink) and consequently, increase in kernel length, kernel girth and kernel weight. The reductions in the kernel length and kernel girth under no irrigation could be attributed to a decrease in the activity of meristematic tissues responsible for elongation, as well as the reduction in photosynthetic efficiency under insufficient water condition (Siddique et al., 1999).

The significant increase in yield of $T$. peruviana could be attributed to greater plant height, number of primary branches per plant and the stem girth which translated into increased number of flowers per plant and subsequently, greater yield. Yield advantage under irrigation could also be attributed to availability of moisture which facilitated nutrients uptake.

The reason for the significant increase in the vegetative growth of the plant when nitrogen fertilizer was applied could be that the native nitrogen in the soil was low and not sufficient for the growth of $T$. peruviana. Similar result was reported by Menzel et al. (1994) who found that a young tree of lychee (Bengal lychee) needed small, split applications of $\mathrm{N}$ to promote each growth flush and develop strong canopies.

Application of $60 \mathrm{~kg} \mathrm{~N} \mathrm{ha}^{-1}$ delayed days to first flower appearance, number of days to $50 \%$ flower appearance, number of days from planting to fruit maturity and number of days from flowering to fruit maturity. This could be as a result of luxury consumption of the nutrients as additional nitrogen use beyond $30 \mathrm{~kg} / \mathrm{ha}$ did not produce commensurate benefits. The result is in line with the observation of Mohammed (1979) who reported that one of the effects of the application of excess nitrogen fertilizer to crops is that the vegetative period is prolonged, resulting in prolonged and delayed crop maturity.

The effect of varying rates of nitrogen fertilizer was not significant on kernel length and kernel girth. This result is in line with the findings of Raese et al. (2007) who revealed that neither fruit size nor trunk girth of apple tree (Malus domestica) was appreciably affected by the different rates of $\mathrm{N}$ fertilizer.

The number and weight of harvested kernels of $T$. peruviana plant were also found to increase significantly with increased rates of nitrogen fertilizer up to $60 \mathrm{~kg} \mathrm{~N} \mathrm{ha}{ }^{-1}$. This can be attributed to some of the functions of nitrogen fertilizer in enhancing greater plant height and higher number of branches produced with the application of nitrogen fertilizer. This result is in line with the findings of Yong et al. (2010) who observed that high $\mathrm{N}$ nutrition improved the overall plant oil yield of Jatropha by increasing the total number of fruits and seeds produced per plant. This is in contrast to the findings of Aboyeji and Olofintoye, (2011) who reported that the seed yield of $T$. peruviana plant was suppressed with increase in nitrogen fertilizer application up to $60 \mathrm{~kg}$ $\mathrm{N} \mathrm{ha}^{-1}$. The dissagreement could be as a result of soil factor or variation in the nutrient status of the native soils caused by the topography of the experimental sites.

The results of the present study indicated that the application of phosphorus fertilizer up to $30 \mathrm{~kg} \mathrm{P}_{2} \mathrm{O}_{5}$ $\mathrm{ha}^{-1}$ increased plant height, number of primary branches and stem girth. This may be due to the fact that phosphorus is one of the major nutrients required by crops in relatively large amounts at the early stage of growth. This finding agrees with that of Das et al. (1991) who reported an increase in height, number of branches and fresh and dry weights of shoots and roots of black cumin (Nigella sativa) with increasing phosphorus application from 20 to $40 \mathrm{~kg} \mathrm{ha}^{-1}$.

The significant reduction in the number of days to first flower appearance, number of days to $50 \%$ flower appearance and fruit maturity with increasing rates of phosphorus fertilizer showed that well P-fertilized $T$. peruviana plants mature earlier than the unfertilized one. This could be attributed to the fact that phosphorus fertilizer is essential for vigorous growth, flowering, fruiting and early fruit maturity (Gayle et al., 2001).

Kernel size and weight of harvested kernels were found to increase with the application of phosphorus fertilizer. This may be due to some of the functions of phosphorus fertilizer in stimulating flower and seed production. This result confirmed the earlier report of Aboyeji and Olofintoye, (2011) who concluded that the application of phosphorus fertilizer improved the kernel yield of $T$. peruviana.

\section{CONCLUSION}

The implication of this study is that factorial combination of irrigation with $30 \mathrm{~kg} \mathrm{~N} \mathrm{ha}{ }^{-1}$ and $30 \mathrm{~kg}$ $\mathrm{P}_{2} \mathrm{O}_{5}$ ha $^{-1}$ will enhance growth and yield of $T$. peruviana. It can therefore be recommended that during the dry season of the first year of field establishment, $T$. Peruviana should be irrigated and given fertilizer at a combination of $30 \mathrm{~kg} \mathrm{~N} \mathrm{ha}^{-1}$ and $30 \mathrm{~kg} \mathrm{P}_{2} \mathrm{O}_{5} \mathrm{ha}^{-1}$ for optimum yield.

\section{REFERENCES}

Aboyeji, C.M. and Olofintoye, J.A. (2011)Growth and yield response of Thevetia periviana J. to applied nitrogen and phosphorus fertilizers in the southern Guinea savannah of Nigeria. Journal of Agronomy 10 (4): 123-127.

Ashraf, M., Nawazish, S. and Athar, H.R. (2007). Are chlorophyll fluorescence and photosynthetic capacity potential physiological determinants of drought tolerance in maize (Zea mays L.)Pak. J. Bot., 39(4):1123-1131.

Assaf, R., Levin, I. and Brawdo, B. (1982). Apple Fruit Growth as a Measure of Irrigation Control. Hort. Sci. 17 (1):

59-61. 
Azam, M.M., Waris, A., and Nahar, N.M. (2005). Prospects and potential of fatty acid methyl esters of some non- traditional seed oils for use as biodiesel in India. Biomass and Bioenergy, 29: 293-302.

Berenguer, J. M, Espoda, M.J. and Gracia, J. L. (2002). Effect of variable water irrigation supply in olive fruit and oil production. Proc. $4^{\text {th }}$. International symposium on olive growing, Acta Horticulturae. 586:341-344.

Das, A.K., Sadhu, M.K, and Som, M,G, (1991). Effect of $\mathrm{N}$ and $\mathrm{P}$ levels on growth and yield of black cumin (Nigella sativa L.) Hort. J., 4: 41-7

Dehghanisanij, H., Naseri, A., Anyoji, H. and Eneji, A.E. (2007). Effects of deficit irrigation and fertilizer use on vegetative growth of drip irrigated cherry trees, J. Plant Nutr., 30: 411-425.

Gayle, S., David, G., and Weiss, R. (2001). Nutrient in Plants. New York: Brooks Printing Company. 3:302-307.

Gomez, K.A. and Gomez, A.A. (1984). Statistical Procedure for Agricultural Research. 2nd Edn.,John Wiley and Sons, New York, USA., ISBN-10: 0471870927, pp: 704.

Gübitz, G.M., Mittelbach, M. and Trabi, M. (1999). Exploitation of the tropical oil seed plant Jatropha curcas L. Bioresource Technol., 67: 73-82.

Ibiyemi, S.A, Fadipe, V.O., Akinremi, O.O. and Bako, S.S. (2002). Variation in oil composition of thevetia peruviana juss seeds. J Appl. Sci. Environ Management 6: (2), 61-65.

Koo, R.Young, W., Reese, L. and Kesterson, J.W. (1974). Effect of nitrogen, potassium and rrigation on yield and quality of lemon. Journal of the American society for Horticultural sciences 99[4], 289-291.

Manchanda, H.R, Sharma, S.K. and Bhandari, D.K. (1982). Response of Barley and Wheat to Phosphorus in the presence of Chloride and Sulphate salinity, Can. J. But 6:233 - 241.

Menzel, C. M., Haydon, G. F., Doogan, V. J. and Simpson, D. R.(1994). Time of nitrogen application and yield of Bengal lychee on a sandy loam soil in sub-tropical Queensland. Australian Journal of Experimental Agriculture 34: 803-11.

Prasad, B. and Shina, N.P. (1981). Balance sheet of soil phosphorus and potassium as influenced by intensive cropping and fertilizer use. Soil and Plants 60: 187 - 193.

Raese, John Thomas, Drake, Stephen R. and Curry, Eric A.(2007). Nitrogen Fertilizer Influences Fruit Quality, Soil Nutrients and Cover Crops, Leaf Color and Nitrogen Content, Biennial Bearing and Cold Hardiness of 'Golden Delicious", Journal of Plant Nutrition, 30:10, 1585-1604. http://www.informaworld.com/smpp/title conte $\mathrm{nt}=\mathrm{t} 713597277$.
SAS, (2000). SAS User's Guide: Statistics. SAS Institute, Cary, NC.

Scheffel, L Richard.(1999). Nutrient Facts (Quick Nutrient Guide Handbook). New York: Brooks Printing Company. 2:70-71.

Shawky, I.,El Tomi, L and Khalil, K. (1973). Effects of nitrogen fertilization on yield and fruit quality of [Balady] orange trees in central Arizona, proceedings of the first International citrus symposium 3, 1569-1578.

Siddique, M.,Hamid, R.B and Islam, M.A. (1999). Drought stress effect on photosynthetic rate and leaf gas exchange of wheat. Botanical Bull. of Academia Sinica, 40: 141-145.

Singh, K., Ram, P. and Singh, J.P. (1989). Effect of nitrogen and inter and intra row spacing on herb and oil yield of transplanted Japanese mint (Mentha arvesis L.). Ann.Agric.Res.,10:258261.

Srivastava, P.K., and Verma, M. (2008). Methyl ester of karanja oil as an alternative renewable source energy. Fuel, 87(8-9), 1673-1677.

Tovar, M.J., Romero, M.P., Girona, M.J., Motilva, M.J. (2002). 1-Phenylalanine ammonia-lyase activity and concentration of phenolics in developing olive (Olea europaea, L. cv. Arbequina) fruit grown under different irrigation regimes. J. Sci. Food Agric. 82, 892-898.

Yin, L., Hu, T.X., Lui, Y.A., Yao, S.F., Ma, J., Liu, W.T and He, C. (2010). Effect of Drought on photosynthetic characteristics and growth of Jatropha curcas seedlings under different nitrogen levels. Ying Yong Sheng Tai Xue Bao, Journal of applied Ecology 21:3:569576.

Yong, J.W.H., Ng, Y.F., Tan, S.N. and Chew, A.Y.L.( 2010). Effect of fertilizer application on photosynthesis and oil yield of Jatropha curcas L. Photosynthetica, 48:208-218. 